\title{
Det starter med et spørsmål
}

Det kan være til god hjelp å stille de rette spørsmålene for å holde seg faglig oppdatert.

\section{Forfatter}

Liv Merete Reinar

Seniorrådgiver

Folkehelseinstituttet

Sykepleien Forskning 2019 14(57454)(e-57454)

DOI: https://doi.org/10.4220/Sykepleienf.2019.57454

Sykepleiere skal være faglig oppdatert.

Forskningsbasert kunnskap bør være en av kildene de henter sin informasjon fra.

\section{Forskningsbasert kunnskap er ikke nok}

For at pasienter skal få best mulig sykepleie, bør alle avgjørelser som tas, være så velinformerte som mulig. Det er her begrepet kunnskapsbasert praksis kommer inn.

Kunnskapsbasert praksis innebærer å integrere pasientens og de pårørendes behov, holdninger og preferanser med kunnskap fra den beste tilgjengelige forskningen og supplere dette med egen erfaring og tilgjengelige ressurser. 
En mye brukt definisjon internasjonalt er denne: «Evidence-based nursing is the process by which nurses make clinical decisions using the best available research evidence, their clinical expertise and patient preferences, in the context of available resources.» (1)

Eller denne på norsk: «Å utøve kunnskapsbasert praksis er å ta faglige avgjørelser basert på systematisk innhentet forskningsbasert kunnskap, erfaringsbasert kunnskap og pasientenes ønsker og behov i en gitt situasjon.» (2)

I en kunnskapsbasert og verdiforankret helsetjeneste bruker helsepersonell all gyldig og relevant informasjon når de planlegger tiltak eller støtter pasienter i å kunne ta velinformerte beslutninger.

\section{Hva er et godt spørsmål?}

Kunnskapsbasert praksis formuleres gjerne i seks trinn (2):

1. Erkjenne informasjonsbehov

2. Stille spørsmål: Informasjonsbehovet kommer fra praksis og formuleres i klare spørsmål

3. Innhente kunnskap: Spørsmålet brukes som basis for litteratursøk for å finne relevant forskningsbasert kunnskap

4. Kritisk vurdere kunnskap: Forskningsbasert kunnskap vurderes kritisk med hensyn til gyldighet og relevans

5. Anvende god kunnskap: Gyldig og anvendbar kunnskap integreres med erfaring og brukerens preferanser for å planlegge og gjennomføre tiltak

6. Evaluere praksis 
Med utgangspunkt i for eksempel et klinisk scenario blir sykepleieren utfordret til å formulere gode spørsmål. Et godt startsted er å gripe fatt i pasientens behov. Det er pasientens situasjon som er utgangspunktet for deg, og det som er viktig for ham eller henne, er viktig for deg. Å stille et godt spørsmål kan ha avgjørende betydning for både jobben og pasienten.

Men å stille spørsmål og søke etter svar er også viktig for fagutviklingen. Dagsaktuelle, presserende spørsmål må besvares her og nå. Ikke alle slike spørsmål kan besvares på stående fot. Enten har du ikke et pålitelig svar i hodet, eller så har du ikke tid til omfattende leting etter svar. Det er en fagutviklingsoppgave. Da blir det viktig at det å stille spørsmål er en del av fagutviklingen blant sykepleiere.

\section{三 «Å stille et godt spørsmål kan ha avgjørende betydning for både jobben og pasienten.»}

Du må skille mellom det å svare på spørsmål som et kollektivt arbeid (gjennom primær- og sekundærforskning) og det å stille spørsmål her og nå. I begge tilfeller er det nyttig å sette sammen spørsmål på en god måte, det vil si på en måte som gjør det lettere å svare på dem.

\section{Kjernespørsmål}

Hva slags kunnskap er medisinsk kunnskap? Er sykepleierkunnskap noe genuint annet enn det legene driver med? Hvilken særskilt kunnskap er det de ulike helseprofesjonene forvalter? Fagutviklingen i helsefagene drives i stor grad fremover av forsøk på å besvare seks spørsmål, også kalt kjernespørsmål (2):

1. Hvor mange har et helseproblem?

2. Hvordan kan vi avgjøre om noen har dette problemet?

3. Hvorfor får noen slike problemer? 
4. Hvordan går det med den som har problemet?

5. Hva kan vi gjøre for å forebygge eller behandle problemet?

6. Hvordan oppleves det å ha dette problemet?

Formulert på en annen måte trengs det kunnskap om

- prevalens (forekomst)

- diagnostikk og tester

- etiologi (årsaksforhold)

- prognose (sykdomsforløp)

- effekt av forebygging, behandling og rehabilitering

- erfaringer og opplevelser

Hvis du tar for deg de mest leste internasjonale tidsskriftene og leter frem artikler som presenterer forskningsfunn, vil omtrent fire av fem studier uten videre kunne kategoriseres etter denne inndelingen. Denne måten å dele inn kunnskap på gjør den medisinske forskningslitteraturen mer oversiktlig.

Den korresponderer også med forskjellige måter å innhente kunnskap på (studie- eller forskningsdesign): Hvis du vil ha svar på spørsmål om en sykdoms årsaker, må du gå frem på en annen måte enn hvis du vil utforske pasientenes tanker, følelser og verdier.

Inndelingen i disse hovedområdene hjelper deg med å holde oversikt over faget og gjør det lettere å innhente og vurdere informasjon. Dette er til god hjelp når du skal holde deg faglig oppdatert. Det er spørsmålet som må avgjøre hvordan du går frem for å innhente kunnskap.

\section{Spørsmål fra praksis}

En grei regel når du skal formulere spørsmål, er å ha klart for deg

- hvem det handler om 
- hvilket virkemiddel (risikofaktor, test, prognostisk faktor eller tiltak) du er interessert $\mathrm{i}$ - og eventuelt hva du sammenlikner med

- hvilke utfall eller endepunkter som er av interesse Disse elementene kan settes inn i tre- eller firedelte spørsmål i en inndeling med «hvem», «virkemiddel» og «utfall». Eller som pasient, tiltak, kontroll og utfall (patient, intervention, control, outcome - PICO).

Dette hjelper deg med å stille praksisrelevante spørsmål, å finne ut hva slags kunnskap du trenger for å besvare spørsmålet (forskningsdesign), og ikke minst med å lage en søkestrategi for å finne den forskningsbaserte kunnskapen. En søkestrategi vil gjerne inneholde elementer fra alle deler av spørsmålet.

For å definere et spørsmål som det går an å svare på, kan vi begynne med å beskrive en situasjon fra hverdagen (3).

\section{Eksempel 1}

En nyfødtavdeling tilbyr sorggrupper til foreldre som har mistet et barn. Dette tiltaket krever mange ressurser. En sykepleier og en barnepleier leder gruppene, ofte i sin fritid og på frivillig basis. Oppslutningen fra brukerne varierer fra gruppe til gruppe. Avdelingssykepleieren mener tilbudet er bra, men det er vanskelig å rekruttere gruppeledere. Finnes det forskning som dokumenterer effekten av sorggrupper? Bør i så fall dette arbeidet prioriteres?

Det kan være nyttig å klassifisere problemstillingen i et skjema for lettere å komme frem til et eller flere klare og konsise spørsmål. Avhengig av hvilket utfall du er mest interessert $i$, vil du kunne formulere ulike spørsmål. Når du skriver spørsmålene helt ut, ser de slik ut: 
- Vil foreldre som tilbys sorggruppe etter å ha mistet et barn, mestre sin situasjon bedre enn dem som bare får rutinemessig oppfølging?

- Vil foreldre som tilbys sorggruppe, være mer tilfredse med oppfølgingen enn dem som får en samtale med barnelegen?

\section{Eksempel 2}

Du er helsesøster. Et foreldrepar ønsker ikke at barnet deres på tre måneder skal ha MMR-vaksine. De er redde for at barnet skal bli autistisk. De har lest $\mathrm{i}$ avisen at vaksinering kan gi autisme. Vaksinering er frivillig. Du ønsker å sette deg inn i forskningen på feltet, slik at du kan bidra til at foreldrene gjør et velinformert valg.

Ved å skrive spørsmålene ut kan de se slik ut:

- For spedbarn som får MMR-vaksine, hva er forekomsten av autisme sammenliknet med barn som ikke får vaksinen?

- For spedbarn som ikke får MMR-vaksine, hva er forekomsten av ettervirkninger fra meslinger?

\section{Eksempel 3}

Du jobber i hjemmesykepleien. Du er kontaktsykepleier for en pasient med langtkommet kreft. Pasienten er i terminalstadiet og har selv tidligere ytret et ønske om å få dø hjemme. Nå er pasienten redd for å være en for stor belastning for familien og lurer på om det hadde vært bedre å flytte på sykehjem.

Du er interessert i om det finnes forskning om pårørende til mennesker som dør hjemme, om deres tanker og opplevelser i ettertid. Finner du slik informasjon, kan du kanskje bidra i diskusjonen med pasient og pårørende før de velger hva de skal gjøre. 
- Hvordan opplever pårørende det når pasienter dør hjemme?

- Hvordan opplever pårørende det når pasienter dør på sykehjem?

Dette er noen forslag til klinisk relevante spørsmål som illustrerer at det trengs ulike forskningsdesign når du skal lete etter forskningsbasert kunnskap. Forenklet kan vi dele inn disse eksemplene slik at det i det første eksempelet trengs svar fra randomiserte, kontrollerte studier og i det andre fra kohortstudier eller kasuskontrollstudier. Du trenger informasjon fra kvalitativ forskning i det tredje eksempelet.

\section{三 «I sykepleien må du alltid avveie fordeler og ulemper for den enkelte pasienten i den enkelte situasjonen.»}

Et viktig prinsipp i kunnskapsbasert sykepleie er at kunnskap fra forskning aldri alene er nok for å ta valg for utøvende sykepleiere. I sykepleien må du alltid avveie fordeler og ulemper for den enkelte pasienten i den enkelte situasjonen. Det er også kostnader og andre avveininger som må vurderes, og i en helhetlig sykepleietjeneste skal pasientens preferanser og verdier være med i vurderingen.

Uansett: Vi verken kan eller ønsker å være kunnskap fra forskning foruten!

Artikkelen bygger blant annet på tidligere publiserte artikler (4-9).

\section{Referanser}

1. DiCenso A, Guyatt G, Ciliska D. Evidencebased nursing: a guide to clinical practice. Elsevier Mosby; 2005.

2. Nortvedt MW, Jamtvedt G, Graverholt B, Nordheim LV, Reinar LM. Jobb kunnskapsbasert! En arbeidsbok. 2. utg. Oslo: Akribe; 2012. 
3. Kunnskapsbasertpraksis.no. [internett]. Oslo: Folkehelseinstituttet; [sitert 06.08.2019]. Tilgjengelig fra: http://www.helsebiblioteket.no/kunnskapsbasertpraksis

4. Reinar LM, Bjørndal A. Kunnskapsbasert praksis. Tidsskrift for jordmødre. 1999;(1-2):17-8.

5. Reinar LM, Bjørndal A. Hva er et godt spørsmål? Tidsskrift for jordmødre. 1999;(1-2):18-20.

6. Reinar LM, Bjørndal A. Å lete etter svar. Tidsskrift for jordmødre. 1999;(3):15-8.

7. Reinar LM, Bjørndal A. Å vurdere kunnskap. Tidsskrift for jordmødre. 1999;(4):15-8.

8. Reinar LM, Bjørndal A. Hva var resultatene? Tidsskrift for jordmødre. 1999;(5):15-8.

9. Reinar LM, Bjørndal A. Å flytte kunnskap ut i praksis. Tidsskrift for jordmødre. 1999;(7-8):15. 